\title{
Editorial
}

\section{Technifications, appropriations, and environmental risk and damage: the search for responsibility}

Despite the differences between the articles published in this edition of the Journal of Human Rights and the Environment, the themes of appropriation, technical apparatuses (both material and discursive) and tensions concerning the uneven imposition of environmental damage and risk are either explicitly or implicitly present. The various articles share a sense - moreover - of how important it is to search for ways to construct responsibility for the imposition of such risk and damage. The Anthropocene climate crisis also presses unevenly into view: sometimes overtly addressed, at other times the inescapable background material situation against which all struggles for accountability and 'responsibilisation' (as Lorraine Code might put it) ${ }^{1}$ must now take place.

The articles here, taken together, raise complex and important matters. In the collisions and convergences between the authors' contributions, a whole continent of possibilities, critiques and lines of thought emerge. One identifiable narrative arc (there may be others) moves along a tangled track between the 'ecologised appropriations' of the Anthropocene (Pottage); the responsibilisation of eco-robotics (eco-robots are emergent forms, arguably, of techno-appropriation) (Donhauser); appropriative dynamics of Eurocentric legal and scientific epistemologies (Townsend); and the tensions between appropriative neoliberal economistic law and the constitutional human right to a clean and healthy environment in Kenya (Mwanza).

The edition opens with Alain Pottage's thought-provoking reflection on 'Holocene jurisprudence'. Set against the geological identification of 'the Anthropocene', Pottage frames Carl Schmitt's Nomos De Erde (Nomos of the Earth) as 'the last flourish of Holocene jurisprudence'. Among the multiple themes emerging in Pottage's article are the distinctively Anthropocene entanglements between geology and the social sciences; the non-naturalistic 'general ecology' marking the Anthropocene; the equivocal place of land as the originary site of appropriative claims, and Anthropocene transmutations of appropriation as a persistent, inherently political, dynamic. Appropriation, Pottage argues, for all available jurisprudences of Anthropocene responsibility, can no longer merely be read as appropriation of land in the traditional Lockean sense, for appropriation also takes place in multiple forms of spoliation (such as the pollutant 'atmosphere-appropriations of the industrial powers'). In the Anthropocene, appropriation is now an ecologized process for which 'ecology' can no longer be just a designation placed over 'nature': the Anthropocene is marked by a 'general ecology' as the contingent effect of a diverse assemblage of 'agencies, media, discourses and temporalities'. Pottage positions Schmitt's 'geojurisprudence' as a

1. L Code, Ecological Thinking: The Politics of Epistemic Location (Oxford University Press, Oxford 2005). 
jurisprudence of the Holocene, rather than of the Anthropocene, because Schmitt grounds his analysis in a terrestrial, elemental, medium that enables Anthropocene appropriations to be subjected to the full normative force of critique directed against the 'land grab'. At the same time, Schmitt's trinitarian scheme of appropriationdistribution-production allows critiques of appropriation to respond to the ecological complexity now marking the general ecology of the Anthropocene.

Pottage's analysis develops the idea that appropriation takes place through the extension of Anthropocene non-natural ecologies as feats of - among other things technification and techno-spoliation. It is against this meaning of appropriation that we can position Justin Donhauser's contribution. In 'Environmental robot virtues and ecological justice', Donhauser sets out to introduce eco-robotics and to construct an ethical framework adequate to its potential implications. Yet, while Donhauser does not himself address environmental robotics as a potential form of technoappropriation, it is clear that key questions related to appropriations are implicated by his analysis: What - precisely - is imposed upon whom - and in which ways - by environmental robotics? How might eco-robots operate as forms of appropriation by spoliation? Whose interests are served by eco-robotic ecological interventions - with what potentially dispossessive or expulsive effects?

Donhauser's article is a response to the fact that robotics technologies are increasingly being used, not only for environmental research, but also as methods for responding to environmental challenges by integrating robots into ecosystems. His concern centres upon the "new roles that robots may play in our environments, potentially crucial new forms of human dependence on such robots, and new ways that robots can promote and enhance well-being'. His response to these concerns is to propose a virtue-centred ethical framework for environmental robotics, which he argues is better able to respond to the complexity of the challenges emerging from the use of eco-robots than are deontological and utilitarian ethical theories. His ethical proposal, refracted through a threefold taxonomical categorization of environmental robots into 'robots-in-ecology', 'robots-for-ecology' and 'ecobots' (ecologically-functionalrobots), is - as the reader might deduce from his emphasis on 'new ways that robots can promote and enhance well-being' - ultimately optimistic. Donhauser's concern is to offer an ethical framework to guide decision-making about the 'ethics, policy and regulation of such technologies before their development outpaces our capacity to make informed and ethical decisions about them'. He deliberately leaves open some of the more critical questions concerning risks and dangers - for future engagement.

Yet one of the key questions, reading Donhauser and Pottage side by side, is the extent to which the eco-technification performed by environmental robotics might prove appropriative. Central to this question, moreover, is the need for critical alertness to the ever-present, familiar risk of entrenching pre-existing colonial patterns of appropriation marking the Anthropocene. And these patterns, as critical scholars point out, reflect capitalist formations for which law was - and remains - a central, mediating function of colonial and neo-colonial juridical appropriations.

A core pattern of such juridical appropriation, familiar to many readers, concerns the 'epistemological colonization' that is the target of indigenous critical engagements with the dominant, Eurocentric legal order. This kind of appropriation - though she does not name it as such - is legible in Dina Lupin Townsend's analysis, 'Silencing, consultation and indigenous descriptions of the world'.

Townsend examines consultation processes relied upon by the Inter-American Court and Commission of Human Rights by subjecting the role of consultation in 
environmental impact assessment processes to a critique inspired by feminist speech act theory. Townsend argues that while the Court and Commission have held that the State must assess the environmental and cultural impacts of a plan or activity, and have also held that consultation is a necessary element of this process, the Court and Commission's interpretation of indigenous testimony concerning environmental impacts amounts to a form of 'illocutionary silencing'. This silencing, she argues, takes place because indigenous environmental impact testimonies are not interpreted as environmental claims and descriptions but only as cultural ones. In short, Townsend argues that when indigenous community members have provided descriptions of their territories and surrounding environments to environmental impact assessment processes, this testimony has been heard, not as it is intended by the community members as claims about the environment, but as a set of claims about the cultural value of the indigenous environment and its component elements. The claims made by affected communities about environmental impacts are simply unheard on their own terms. Townsend's argument is made, in part, through an examination of the case of Kichwa Indigenous People of Sarayaku v Ecuador. She argues that in this case, the 'Court treats indigenous testifiers as only making claims about cultural beliefs and practices despite the fact that it appears that the testifiers intend to make claims that describe the environment'. Townsend suggests that the epistemic injustice here takes the form of 'linguistic injustice'. The implication of her analysis, Townsend suggests, is that there is a fundamental failure to recognise indigenous descriptions of the environment, a fact with 'important implications for impact assessments, the manner in which they are conducted and whether consultation is "informed".

This interpretive imposition of silence can, I suggest, be read as an appropriation of epistemic authority. This appropriation takes place through the operation of a kind of technicism: the exclusive truth-value imputed to scientific, technical assessments over indigenous community assessments of the relevant impacts upon the environment as experienced, read, understood and inhabited by them. In this sense, then, the thread of appropriation, so powerfully traced by Pottage, and the related thread of technification, core to Donhauser's concerns, emerge in a convergence between traces of both dynamics in Townsend's analysis. The indigenous community is silenced, in Townsend's sense of illocutionary silencing, by an epistemic appropriation of 'the authority to know', mediated by the elevation of Western scientific technical knowledge, which - as Townsend suggests - is assumed to be a fundamentally $a$-cultural mode of knowledge production. Such epistemic appropriation is also, we should note, heavily freighted with the methodological coloniality key to Eurocentric corporate colonial and neo-colonial dynamics.

Appropriation as spoliation, and the enduring operation of Eurocentric corporate coloniality, also emerge as critical threads in the contribution of Rosemary Mutheu Mwanza. In 'Harnessing the transformative potential of the constitutional human right to a clean and healthy environment in the context of corporate environmental damage in Kenya: a critical perspective', Mwanza - without overtly mentioning it as a core analytical concern, nonetheless responds to the problem of appropriation by environmental spoliation in Kenya, noting the inherently economistic tilt of Kenyan law. Kenyan law, she suggests, is shaped by the supremacy of an 'economic rationality that prioritizes economic growth and profit maximization above all else'. Set against the rapid rise of the extractive industry in Kenya - which Mwanza links emphatically to neoliberalism's profit imperative and to its fossil-fuel path dependencies her argument is that law always leans towards the "benefit of corporate perpetrators of harm'. The upstream energy industry in Kenya, 'reflects the triumph of predominantly 
neoliberal economic ideals of profit maximization and economic growth' - and it is against this (appropriative) dynamic that Mwanza positions the Kenyan constitutional human right to a clean and healthy environment as a potentially resistive force.

Taking the right, and grounding it in values committed to the primacy of human and ecological well-being, for Mwanza, produces a 'new norm' - as a reflection of an alternative rationality, constituted by values different from those driving current legal and institutional responses to environmental damage in Kenya. This new norm introduces, therefore, a new set of values into the central confrontation between two orders of meaning in law, one that 'facilitates the externalization of the costs of environmental damage to the advantage of corporate perpetrators', the other being the constitutional human right to a clean and healthy environment ('law's response'). Mwanza argues that the right can be an effective instrument in the search for corporate accountability and for the prevention of corporate environmental harms if the right is constructed in such a way as to prioritize the protection and well-being of humans and ecosystems. In this respect, Mwanza's ethical project has resonances with that of Donhauser, who likewise foregrounds human and ecological well-being in his ethical project. Mwanza attempts to ground a new norm that 'embodies the values of a maximalist notion of human well-being to guide legal responses to the humanitarian and environmental consequences of environmental damage'. However, given the anthropocentrism central to human rights, the full normative force of this suggestion requires a complementary framework of 'an environmental rule of law that is founded on the maximum well-being of ecosystems as the starting point for the exercise of environmental governance powers'. It is difficult to resist the impression that corporate juridical privilege is a core conduit for the current legitimation of appropriation by spoliation and that what is at stake in the enactment of both the norm and its complementary framework is resistance to forms of appropriation that are driving, and enacted by, environmental - and to this we could add climate - spoliation.

The challenges presented by appropriative environmental spoliation and by the urgent need to find new forms and avenues of Anthropocene responsibility in the face of climate emergency, brings us, in a sense, full circle to some of the concerns haunting Pottage's opening reflection on Holocene jurisprudence.

Perhaps there is, after all, a spectral and important Holocene jurisprudential trace in contemporary law. Perhaps it emerges, inconsistently, sometimes through inhospitable apertures, far from strong, but emitting signs of an expanding critical energy. If there is one convergent message from the contributions to this edition it is surely that the need to call to account and to resist present and future Anthropocene appropriations - of various kinds - is now the most urgent of philosophical, jurisprudential, legal and ethical tasks.

Anna Grear

Co-Editor in Chief, Professor of Law and Theory, Cardiff Law School 